\title{
Development of an oxygen-rich biosensor using enzymatic reaction
}

\author{
Yue Cui*, John P. Barford and Reinhard Renneberg \\ Department of Chemical Engineering and Department of Chemistry, Hong Kong University of \\ Science and Technology, Clear Water Bay, Kowloon, Hong Kong \\ *Author for correspondence (Fax: +852-23580054; Email: kecuiyue@ust.hk)
}

Key words: Biosensor, oxygen, catalase; hydrogen peroxide 


\begin{abstract}
This work reports a novel strategy for the development of an oxygen-rich biosensor. The principle is based on an enzymatic reaction between catalase and hydrogen peroxide to release oxygen, thus to increase the oxygen amount in the enzyme matrix. This method improves the determination reliability by alleviating the oxygen dependence.
\end{abstract}

\title{
Introduction
}

The importance of amperometric biosensors has increased considerably in recent years thanks to the advantages of being highly sensitive, rapid, accurate, economical, and easy to handle (Frew \& Hill 1987, Scheller et al. 1991, Turner 2005). The biochemical reactions involving oxygen as a reactant are widely used for the constructions of amperometric biosensors. However, these biosensors suffer from problems in some applications, such as bioprocess monitoring and in-vivo measurement, due to the restriction of oxygen solubility or the fluctuation of oxygen concentration, which result in a narrow linear detection range or an unsteady result (Zhang \& Wilson 1993, Wang 2001).

Various strategies have been developed to solve these problems which resulted from the oxygen dependence, by using a proper membrane coverage to improve the relative surface availability to oxygen while presenting a diffusion barrier to the substrate (Clark et al. 1986, Zhang \& Wilson 1993), by replacing oxygen with an artificial electron-acceptor (Cass et al. 1984, 
Frew \& Hill 1987), or by designing oxygen-rich biocomposite electrode materials (Wang and Lu 1998, Wang et al. 2000, Wang et al. 2001, Wang et al. 2002).

This work reports a novel strategy for designing an oxygen-rich biosensor using an enzymatic reaction between catalase and $\mathrm{H}_{2} \mathrm{O}_{2}$, which can be employed for some in-vitro applications, such as bioprocess monitoring, where the atmosphere $\mathrm{O}_{2}$ fluctuation affects the process performance significantly (Namdev et al. 1993). The Clark-type oxygen electrode is one of the most typical oxygen-detecting electrodes, having been used for the developments of various biosensors, and the oxygen-permeable membrane in the front of the electrode, such as the Teflon membrane, makes the determinations of analytes free from electroactive interferences (Jobst et al. 1993, Chan et al. 1999, Mak et al. 2003). The measurements of glucose with glucose oxidase (GOD) based biosensors have been widely performed in clinical diagnosis, food analysis and bioprocess monitoring (Bradley and Schmid 1991, White et al. 1996, Wang 2001). Therefore, in this work, glucose is used as a representative parameter to construct an oxygen-rich biosensor based on a Clark-type oxygen electrode.

\section{Materials and methods}

\section{Apparatus}

A potentiostat (Biometria EP30, Germany) and a computer installed with software FIABOLO were used. The Clark-type oxygen electrode (model SEM1/4, Elbau, Germany) was composed of 
a Pt working electrode (diameter: $0.5 \mathrm{~mm}$ ) and an $\mathrm{Ag} / \mathrm{AgCl}$ reference/counter electrode. A stirred measuring cell (volume: $1 \mathrm{ml}$ ) was used for the experiments.

\section{Materials}

Glucose, glucose oxidase (GOD, EC 1.1.3.4, from Aspergillus Niger), catalase (EC 1.11.1.6, from Bovine Liver), disodium hydrogen phosphate, sodium dihydrogen phosphate, nafion ${ }^{\circledR}$ perfluorinated resin solution (5 wt. \% in lower aliphatic alcohols and water), and hydrogen peroxide $\left(\mathrm{H}_{2} \mathrm{O}_{2}\right)$ were all reagent grade purchased from Sigma-Aldrich (USA). The nitrogen $\left(\mathrm{N}_{2}\right)$ and oxygen $\left(\mathrm{O}_{2}\right)$ gases were supplied from HKO (Hong Kong). Saturated potassium chloride gel was from Bio Sensor Technologies (Germany). Teflon membrane was from Biological Systems Inc. (USA). Dialysis membrane was from SensLab (Germany).

\section{Preparation of biosensors}

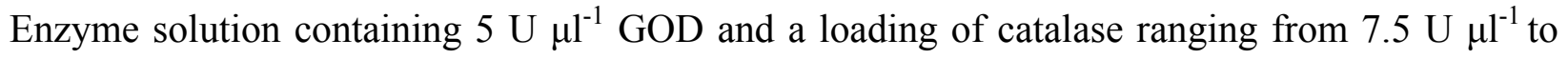

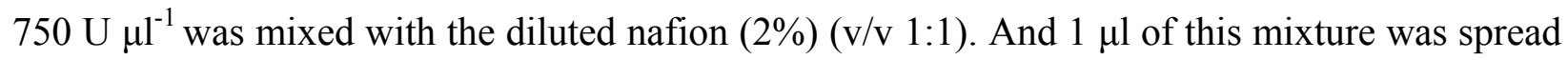
over a Teflon membrane, followed by drying and storing at $4{ }^{\circ} \mathrm{C}$ overnight. The enzyme layer sandwiched between a Teflon membrane and a dialysis membrane was fixed on the top of the Clark-type oxygen electrode with a membrane holder and an O-ring. The Teflon membrane facing toward the oxygen electrode received $15 \mu \mathrm{l}$ of saturated potassium chloride gel as 
electrolyte before assembling the sensor. The sensor was then screwed into a measuring cell, which was filled with buffer solution, and rehydrated for around 30 min before usage.

Procedure for measurements

The $\mathrm{O}_{2}$ removal was attained by purging the buffer solution with $\mathrm{N}_{2}$ gas (for $1 \mathrm{~min}$ ), the $\mathrm{N}_{2}$ atmosphere was subsequently maintained over the solution, and the complete $\mathrm{O}_{2}$ removal was observed when the background current decayed to a constant value which was around zero nA. The $\mathrm{O}_{2}$ saturation was attained by purging the buffer solution with $\mathrm{O}_{2}$ gas (for $1 \mathrm{~min}$ ), an $\mathrm{O}_{2}$ atmosphere was subsequently maintained over the solution, and the $\mathrm{O}_{2}$ saturation was observed when the background current reached a constant high value.

Experiments were performed by applying the desired potential to the Clark electrode at -0.6 $\mathrm{V}$ versus $\mathrm{Ag} / \mathrm{AgCl}$ for the reduction of $\mathrm{O}_{2}$ and magnetically stirring the buffer solution at 300 rpm to obtain a uniform distribution of substrate. When a constant background current was obtained, substrate e was added into the buffer solution so as to give a desired concentration, and until a stationary current, the current difference was recorded in order to plot the current-concentration curve. All measurements were carried out in phosphate buffer (PBS, 50 $\mathrm{mM}, \mathrm{pH} 6.8)$ at room temperature $\left(20^{\circ} \mathrm{C}\right)$.

\section{Results and Discussion}


Construction of the oxygen-rich glucose biosensor

As shown in Figure 1, the principle is as follows: when a constant glucose flux enters the enzyme matrix, the glucose and $\mathrm{O}_{2}$ in the enzyme matrix are consumed by GOD to generate gluconolactone and $\mathrm{H}_{2} \mathrm{O}_{2}$, thus the $\mathrm{O}_{2}$ amount in the enzyme matrix affects the GOD-catalyzed reaction significantly due to being a reactant. In order to provide an enough amount of $\mathrm{O}_{2}$ for the enzymatic reaction by GOD under conditions with $\mathrm{O}_{2}$ fluctuation or restricted $\mathrm{O}_{2}$ solubility, we employ catalase in the enzyme matrix and $\mathrm{H}_{2} \mathrm{O}_{2}$ in the buffer solution to release oxygen, thus to increase the oxygen amount in the enzyme matrix. The amount of $\mathrm{H}_{2} \mathrm{O}_{2}$ produced from glucose is proportional to the $\mathrm{O}_{2}$ concentration in the enzyme matrix, and it can also serve as a supply for enzymatic reaction by catalase, while in the absence of $\mathrm{H}_{2} \mathrm{O}_{2}$ in buffer, its amount would be quite small under atmosphere $\mathrm{O}_{2}$-deficit conditions, thus there is a need for the presence of $\mathrm{H}_{2} \mathrm{O}_{2}$ in buffer solution. By using this method, the $\mathrm{O}_{2}$ concentration in the enzyme matrix can be increased significantly due to the $\mathrm{O}_{2}$ release from $\mathrm{H}_{2} \mathrm{O}_{2}$ by catalase.

Investigation of the $\mathrm{O}_{2}$ release from $\mathrm{H}_{2} \mathrm{O}_{2}$ by catalase

The Clark-type electrode is based on the detection of $\mathrm{O}_{2}$, thus, the electrode current is a reflection of the $\mathrm{O}_{2}$ amount in the enzyme matrix. In order to examine the ability of the catalase-based enzymatic reaction for the release of $\mathrm{O}_{2}$ from $\mathrm{H}_{2} \mathrm{O}_{2}$, the biosensors were constructed with a constant GOD loading and different catalase, $\mathrm{H}_{2} \mathrm{O}_{2}$ loadings. 
Figure 2 compares the current responses of the biosensors with different catalase loadings in the enzyme matrices ranging from $3.75 \mathrm{U}$ to $375 \mathrm{U}$, to various injections of $\mathrm{H}_{2} \mathrm{O}_{2}$ with concentrations ranging from 0 to $2 \mathrm{mM}$ in buffer. As shown in the figure, with the increasing of $\mathrm{H}_{2} \mathrm{O}_{2}$ concentration in buffer, the current increased in the investigated range due to the increasing release of $\mathrm{O}_{2}$ from $\mathrm{H}_{2} \mathrm{O}_{2}$ in the enzyme matrix. However, when the $\mathrm{H}_{2} \mathrm{O}_{2}$ concentration was too high, the current became unsteady as the time went on. Therefore, a $\mathrm{H}_{2} \mathrm{O}_{2}$ concentration at $1 \mathrm{mM}$ in buffer was used for other investigations which can result in a steady background current for the measurement of glucose. Also, the sensors with different catalase loadings exhibited different current responses. When the catalase loading was too low, the rate of the enzymatic reaction was also too low to release a high amount of $\mathrm{O}_{2}$; when the catalase loading was too high, it presented a diffusion barrier and the $\mathrm{H}_{2} \mathrm{O}_{2}$ in buffer was consumed too fast, consequently, the $\mathrm{H}_{2} \mathrm{O}_{2}$ flux entering the enzyme matrix was not constant and the current was followed inconstant. The optimized catalase loadings obtained in the investigated range were $7.5 \mathrm{U}$ and $75 \mathrm{U}$ in the enzyme matrix. Therefore, a catalase loading at $7.5 \mathrm{U}$ in the enzyme matrix was used for further experiments due to the high $\mathrm{O}_{2}$ production with a low loading of catalase.

\section{Detection of glucose under different atmosphere conditions}

Figure 3 compares the current responses to various concentrations of glucose under three different atmosphere conditions in the measuring cell $-\mathrm{O}_{2}$ saturated condition, ambient air, and 
$\mathrm{O}_{2}$ deficit condition. In all three cases, the sensor performances were investigated in the presence of $\mathrm{H}_{2} \mathrm{O}_{2}$ and in the absence of $\mathrm{H}_{2} \mathrm{O}_{2}$.

As the glucose concentration was proportional to the $\mathrm{O}_{2}$ consumption in the enzyme matrix, the amount of $\mathrm{O}_{2}$ in the enzyme matrix was a reflection of its detection range. The $\mathrm{O}_{2}$ supplied by the ambient air provided an enough $\mathrm{O}_{2}$ loading for the enzymatic reaction by GOD, therefore, when the $\mathrm{O}_{2}$ amount in the enzyme matrix was similar to or higher than that obtained under ambient air, the sensitivity to glucose, which was proportional to the current slope, did not change significantly.

In the first case, under $\mathrm{O}_{2}$ saturated condition, $\mathrm{O}_{2}$ gas was used to saturate the $\mathrm{O}_{2}$ concentration in buffer solution, which provided a large amount of $\mathrm{O}_{2}$ for the enzymatic reaction by GOD, compared to this, the release of $\mathrm{O}_{2}$ from $\mathrm{H}_{2} \mathrm{O}_{2}$ by catalase was in a small amount. Due to the high concentrations of $\mathrm{O}_{2}$ in the enzyme matrix both in the presence of $\mathrm{H}_{2} \mathrm{O}_{2}$ and in the absence of $\mathrm{H}_{2} \mathrm{O}_{2}$ in buffer (a. and b.), the detection ranges were quite similar and both were broadened significantly compared to that under ambient air. The sensitivities in the linear detection ranges were also similar to that under ambient air.

In the second case, under ambient air, the sensor in the presence of $\mathrm{H}_{2} \mathrm{O}_{2}$ showed a broader detection range for glucose (c. ambient air $+\mathrm{H}_{2} \mathrm{O}_{2}$ ) than that in the absence of $\mathrm{H}_{2} \mathrm{O}_{2}$ (d. ambient air), which was resulted from the higher $\mathrm{O}_{2}$ concentration in the enzyme matrix due to the release 
of $\mathrm{O}_{2}$ from $\mathrm{H}_{2} \mathrm{O}_{2}$ by catalase. Both situations (c. and d.) showed similar sensitivities in the linear detection ranges.

In the third case, under $\mathrm{O}_{2}$ deficit condition, $\mathrm{N}_{2}$ gas was used to drive out the $\mathrm{O}_{2}$ in buffer solution contained in the measuring cell to ensure the absence of $\mathrm{O}_{2}$ supplied by the ambient air in the enzyme matrix. As shown in the figure, in the absence of $\mathrm{H}_{2} \mathrm{O}_{2}$ (f. $\mathrm{N}_{2}$ ), the current response was nearly zero for the detection of glucose, making the determination impossible. While in the presence $\mathrm{H}_{2} \mathrm{O}_{2}$ in the buffer (e. $\mathrm{N}_{2}+\mathrm{H}_{2} \mathrm{O}_{2}$ ), there was sufficient $\mathrm{O}_{2}$ in the enzyme matrix for the GOD-catalyzed reaction due to the release of $\mathrm{O}_{2}$ from $\mathrm{H}_{2} \mathrm{O}_{2}$ by catalase, though the $\mathrm{O}_{2}$ in the measuring cell supplied by the ambient air had been driven out by $\mathrm{N}_{2}$ gas, and the sensitivity (e.) in the linear detection range was similar to that under ambient air (d.), as shown in the figure.

Hence, the biosensor using the enzymatic reaction between catalase and $\mathrm{H}_{2} \mathrm{O}_{2}$ resulted in accurate measurements for glucose under different atmosphere conditions $\left(\mathrm{O}_{2}\right.$ saturated condition, ambient air, and $\mathrm{O}_{2}$ deficit condition) by alleviating the oxygen dependence, which ensures the reliable determination under conditions with $\mathrm{O}_{2}$ fluctuation or restricted $\mathrm{O}_{2}$ solubility.

Stabilities of GOD and catalase in measurements 
The stabilities of the immobilized enzymes of the oxygen-rich glucose biosensor, including GOD and catalase, were investigated by performing different measurements. During this study, the enzyme matrix on electrode was subjected to a continuous exposure to buffer solution and stressed with an 8-hours continuous stirring.

Figure 4 shows the stabilities of GOD in the enzyme matrices for 250 continuous measurements of glucose in the presence and absence of $\mathrm{H}_{2} \mathrm{O}_{2}$. As shown in Figure 4 (A), GOD did not lose its activity when being exposed continuously to $\mathrm{H}_{2} \mathrm{O}_{2}$ over these measurements, which resulted in a similar stable detection performance as that in the absence of $\mathrm{H}_{2} \mathrm{O}_{2}$ (Figure 4 (B)) thanks to the inborn high stability of GOD. The slight increases of the signal responses during measurements in both cases were probably due to the slight increases of the GOD activities. Therefore, the oxygen-rich glucose biosensor maintained a high working stability for the detection of glucose.

Figure 5 shows the stability of catalase in the enzyme matrix for 250 continuous measurements of $\mathrm{H}_{2} \mathrm{O}_{2}$. Catalase maintained a high stability ( $\left.>90 \%\right)$ for these measurements, and the slight loss of its activity was probably due to the continuous exposure to $\mathrm{H}_{2} \mathrm{O}_{2}$ in measurements. Therefore, the enzymatic reaction by catalase and $\mathrm{H}_{2} \mathrm{O}_{2}$ provides a stable release of $\mathrm{O}_{2}$ for the oxygen-rich biosensor.

\section{Conclusion}


In this work, we have demonstrated a new strategy for the development of an oxygen-rich biosensor using enzymatic reaction between catalase and $\mathrm{H}_{2} \mathrm{O}_{2}$. This method improves the determination reliability by alleviating the oxygen dependence. Such biosensor could be used in some in-vitro applications where there are fluctuations of $\mathrm{O}_{2}$ concentration or restrictions of $\mathrm{O}_{2}$ solubility. Also, the successful construction of the oxygen-rich glucose biosensor provides new possibilities for the developments of other kinds of oxygen-rich biosensors which involve $\mathrm{O}_{2}$ as a reactant in reactions by several classes of enzymes (such as oxidase, hydroxylase), or enzyme combinations, etc.

\section{Acknowledgement}

The authors greatly acknowledge Hong Kong Research Grant Council for the financial support (HKUST6253-02P and 510-0091-02-44000-0).

\section{References}

Bradley J, Schmid RD (1991) Optimization of a biosensor for insitu fermentation monitoring of glucose concentration. Biosens. Bioelectron. 6: 669-674.

Cass AEG, Davis G, Francis GD, Hill HAO, Aston WJ, Higgins IJ, Plotkin EV, Scott LDL, Turner APF (1984) Ferrocene-mediated enzyme electrode for amperometric determination of glucose. Anal. Chem. 56: 667-671. 
Chan CY, Lehmann M, Tag K, Lung M, Kunze G, Riedel K, Gruendig B, Renneberg R (1999) Measurement of biodegradable substances using the salt-tolerant yeast Arxula adeninivorans for a microbial sensor immobilized with poly(carbamoyl) sulfonate (PCS) part I: Construction and characterization of the microbial sensor. Biosens. Bioelectron. 14: 131-138.

Clark LC, Noyles LK, Spokane RB, Sudan R, Miller ML (1986) Design and long-term performance of surgically implantable electroenzymatic glucose sensors. Ann. N. Y. Acad. Sci.

Frew JE, Hill HA (1987) Electrochemical biosensors. Anal. Chem. 59: 933A-944A.

Jobst G, Urban G, Jachimowicz A, Kohl F, Tilado O, Lettenbichler I, Nauer G (1993) Thin-film Clark-type oxygen sensor-based on novel polymer membrane systems for in-vivo and biosensor applications. Biosens. Bioelectron. 8:123-128.

Mak KKW, Wollenberger U, Scheller FW, Renneberg R (2003) An amperometric bi-enzyme sensor for determination of formate using cofactor regeneration. Biosens. Bioelectron. 18:1095-1100.

Namdev PK, Irwin N, Thompson BG, Gray MR (1993) Effect of oxygen fluctuations on recombinant Escherichia-coli fermentation. Biotechnol. Bioeng. 41: 666-670.

Scheller FW, Hintsche R, Pfeiffer D, Schubert F, Riedel K, Kindervater R (1991) Biosensors-Fundamentals, applications and trends. Sensor. Actuat. B-Chem. 4: 197-206. 
Turner APF (2005) Biosensors and bioelectronics 20 years on. Biosens. Bioelectron. 20: 2387-2387.

Wang J (2001) Glucose biosensors: 40 years of advances and challenges. Electroanal.13: 983-988.

Wang J, Chen L, Chatrathi MP (2000) Evaluation of different fluorocarbon oils for their internal oxygen supply in glucose microsensors operated under oxygen-deficit conditions. Anal. Chim. Acta 411: 187-192.

Wang J, Li SF , Mo JW, Porter J, Musameh MM, Dasgupta PK (2002) Oxygen-independent poly(dimethylsiloxane)-based carbon-paste glucose biosensors. Biosens. Bioelectron. 17: 999-1003.

Wang J, Lu F (1998) Oxygen-rich oxidase enzyme electrodes for operation in oxygen-free solutions. J. Am. Chem. Soc. 120: 1048-1050.

Wang J, Mo JW, Li SF, Porter J (2001) Comparison of oxygen-rich and mediator-based glucose-oxidase carbon-paste electrodes. Anal. Chim. Acta 441: 183-189.

White SF, Tothill IF, Newman JD, Turner APF (1996) Development of a mass-producible glucose biosensor and flow-injection analysis system suitable for on-line monitoring during fermentations. Anal. Chim. Acta 321:165-172. 
Zhang YN, Wilson GS (1993) In-vitro and in-vivo evaluation of oxygen effects on a glucose-oxidase based implantable glucose sensor. Anal. Chim. Acta 281: 513-520. 


\section{Figure legends}

Fig. 1. Schematic representation for the construction of oxygen-rich glucose biosensor.

Fig. 2. Investigation of the $\mathrm{O}_{2}$ release from $\mathrm{H}_{2} \mathrm{O}_{2}$ by catalase $(\mathrm{n}=3)$ (Sensor: $2.5 \mathrm{U}$ GOD, a loading of catalase, and 1\% nafion in $1 \mu \mathrm{l}$ of matrix per membrane. Buffer: $50 \mathrm{mM} \mathrm{PBS}$ at $\mathrm{pH}$ $6.8)$.

Fig. 3. Detection of glucose under different atmosphere conditions $(n=3)$ (Sensor: 2.5 U GOD, $7.5 \mathrm{U}$ catalase, and $1 \%$ nafion in $1 \mu \mathrm{l}$ of matrix per membrane. Buffer: $50 \mathrm{mM}$ PBS containing 1 $\mathrm{mM} \mathrm{H}_{2} \mathrm{O}_{2}$ at $\mathrm{pH}$ 6.8).

Fig. 4. Stabilities of GOD in the enzyme matrices for 250 continuous measurements of glucose performed in (A) $50 \mathrm{mM}$ PBS containing $1 \mathrm{mM} \mathrm{H}_{2} \mathrm{O}_{2}$ at pH 6.8 and (B) $50 \mathrm{mM}$ PBS at pH 6.8 $(\mathrm{n}=3)$ (Sensor: $2.5 \mathrm{U}$ GOD, $7.5 \mathrm{U}$ catalase, and 1\% nafion in $1 \mu$ of matrix per membrane. Substrate: $2 \mathrm{mM}$ glucose). The relative response (\%) was calculated by normalizing the signal to the initial signal of these measurements.

Fig. 5. Stability of catalase in the enzyme matrix for 250 continuous measurements of $\mathrm{H}_{2} \mathrm{O}_{2}(\mathrm{n}=3)$ (Sensor: $2.5 \mathrm{U}$ GOD, $7.5 \mathrm{U}$ catalase, and 1\% nafion in $1 \mu \mathrm{l}$ of matrix per membrane. Buffer: 50 $\mathrm{mM}$ PBS at $\mathrm{pH}$ 6.8. Substrate: $1 \mathrm{mM} \mathrm{H}_{2} \mathrm{O}_{2}$ ). The relative response (\%) was calculated by normalizing the signal to the initial signal of these measurements. 


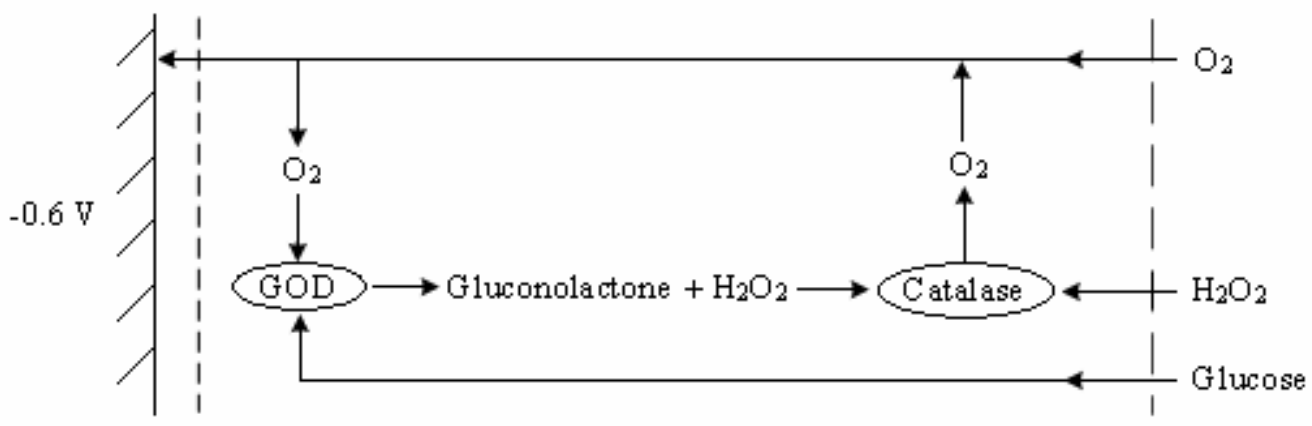

Fig. 1 


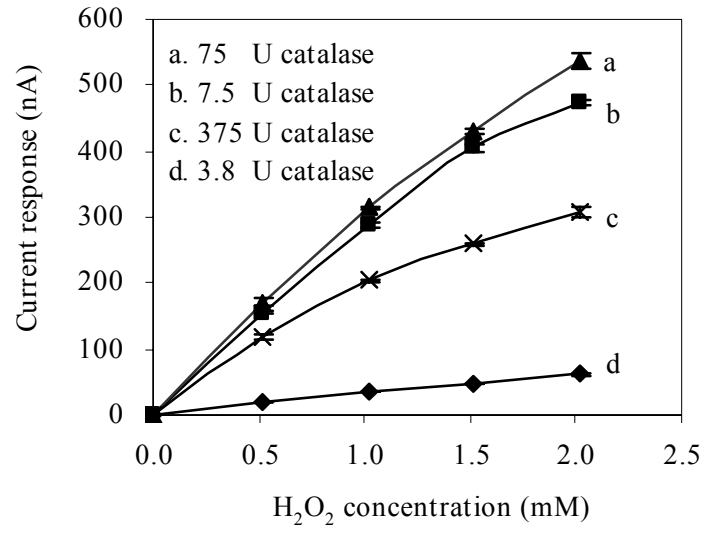

Fig. 2 


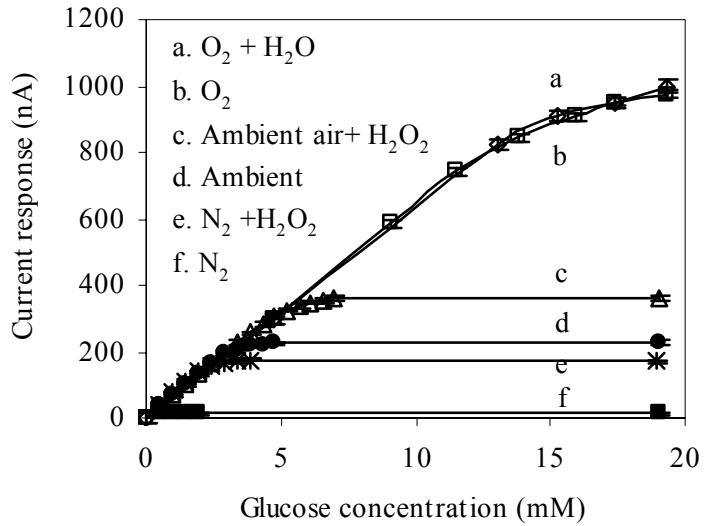

Fig. 3 

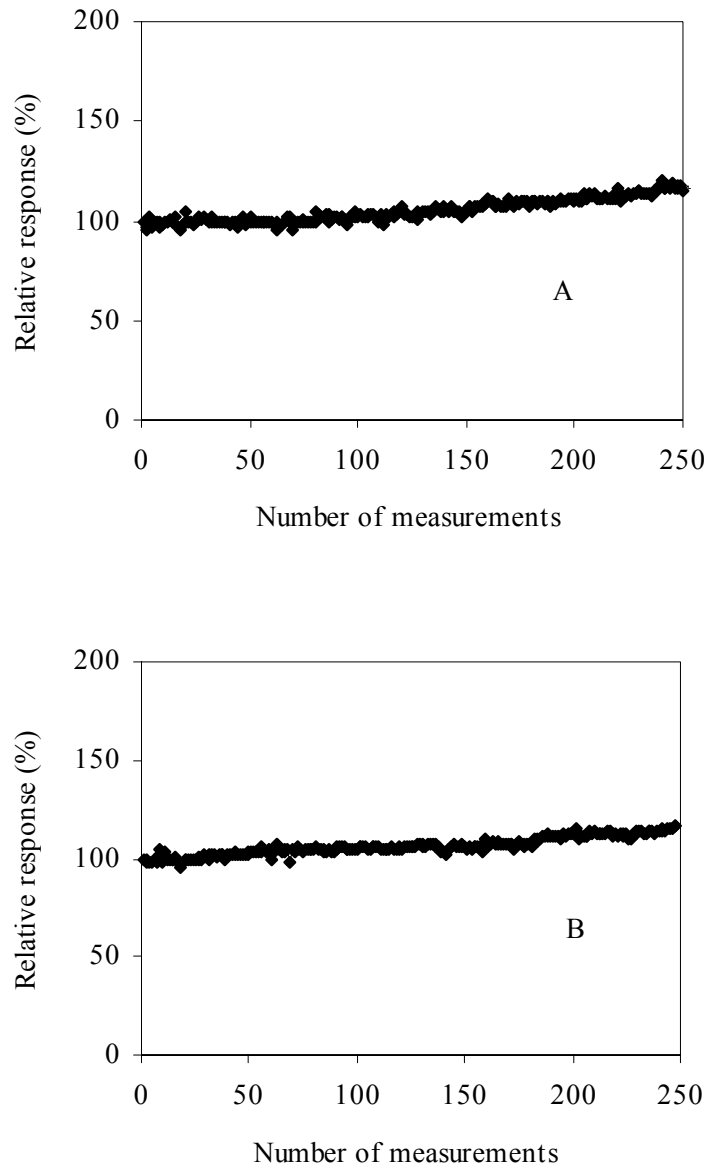

Fig. 4 


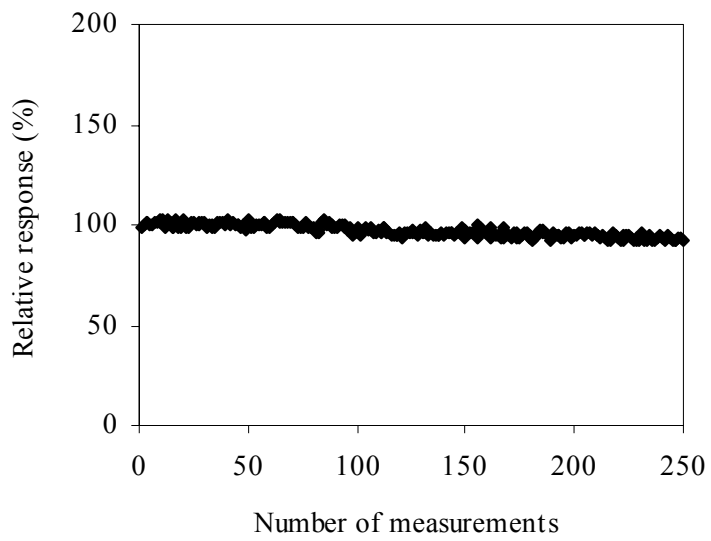

Fig. 5 